\title{
Physiological age in Lutzomyia youngi (Diptera: Psychodidae) populations from an endemic area for cutaneous leishmaniasis, Venezuela*
}

\author{
José V. Scorza**, Milagros Oviedo**
}

\begin{abstract}
SCORZA, J. V. \& OVIEDO, M. Physiological age in Lutzomyia youngi (Diptera: Psychodidae) populations from an endemic area for cutaneous leishmaniasis, Venezuela . Rev. Saúde Pública, 28: $400-5,1994$. Batches of sylvatic females of Lutzomyia youngi (Phlebotominae) captured in a Shannon trap on twelve occasions over one year in a locality where subcutaneous leishmaniasis is endemic, near the city of Trujillo, Venezuela, were used to study: 1) the percentages of parous females according to previously established criteria and 2) the average number of eggs laid spontaneously by isolated females during 7 days after feeding on hamsters. The data on the batches of females captured on nights previous to the rainy period (prepluvial) were compared with those on females captured after the rains (postpluvial). Significant differences were detected by variation analysis for two variables and different number of $\mathrm{N}$, as also were consistent groupings by Duncan's Test for pre-and postpluvial lots of females. The females captured on nights prior to the rainy periods (January-March and August-September) presented higher rates of nulliparity (86-72\%) and contained or laid a greater number of eggs (71-67) than those captured after the rains (March-June and November-December) which presented lower rates of nulliparity (60-24\%) and a smaller number of eggs (50-30). The tainfall peaks occurred in April and September-October, respectively. It is considered that these differences can be used by epidemiological studies as a means of estimating the physiological age of female populations of $L$. youngy.
\end{abstract}

Keywords: Psychodidae, physiology. Oviposition, physiology. Ecology, vectors.

\section{Introduction}

In the suburban areas of the city of Trujillo, Venezuela, with 48,000 inhabitants, approximately 130 cases of cutaneous leishmaniasis are encountered yearly (Scorza et al. $.^{9}, 1988$ ), principally in women and children (Scorza et al ${ }^{7}$., 1985). The vector Leishmania braziliensis in this region is Lutzmyia youngi Murillo \& Zeledon, 1985 , until recently confused with $L$. townsendi (Ortiz, 1959); it has been found naturally infected, together with infected Didelphis marsupialis at the sites of active transmission (Scorza et al. ${ }^{6.8}, 1984,1986$ ).

To reduce the risk of human infection, it is necessary to determine the population dynamics of this vector, for the rational use of aerosol insecticides, bearing in mind its extradomiciliary habitat.

There has recently been intensive investigation of the physiological age of female phlebotomines reared in the laboratory. Ready

\footnotetext{
* Supported by the "Consejo de Desarrollo Científico, Humanístico y Tecnológico, ULA. Venezuela". Proyecto NURR C. 48.

** Centro Trujillano de Investigaciones "José W. Torrealba" - Venezuela

Reprints: J.V.Scorza - Apartado 100 - Trujillo - Venezuela
}

et al..$^{5}$ (1984) and Magnarelli et al. ${ }^{2}$ (1984) have described follicular dilatations in parous females of $L$. flaviscutellata and $L$. furcata, and in $L$. longipalpis and L. anthophora, respectively. The former authors describe the "swellings" as containing remnants of nutritive cells and follicular epithelium, while the latter authors describe them as "loosely defined" and containing cellular remnants. In neither case could the parity of the females be determined experimentally, due to the high mortality of $L$. longipalpis or to technical difficulties: 4-6 min. were needed to dissect one female, there was therefore "no point in going further than a simple nulliparous or parous classification".

A previous paper (Márguez \& Scorza ${ }^{4}, 1982$ ) which has described for the first-time, in wild and in laboratory-reared females of $L$. youngi, certain to have laid eggs, "the presence of an ovarian calyx with membranes, globules, and melanin granules as unmistakeable signs of a complete blood meal and of oviposition", added: "In all (parous experimental females) besides follicles with oocytes and nutritive cells of normal appearance, we found a complex system of interfollicular membranes with accumulations of granular material of appearance similar to melanin" (our italics).

Dissection of more than 20,000 wild-caught 
female $L$. youngi from non-endemic areas near our work site, these being used for xenodiagnosis, has convinced us that parous females produce fewer eggs than primiparas Ward (1977), however, affirms the contrary for $L$. flaviscutellata: "there was no significant variation in egg production with repeated ovipositions".

This difficulty of colonizing $L$. young $i$, due to the high mortality of egg-laying females in the laboratory, plus the necessity of developing some criterion of multiparity, has led us to compare, from each lot of insects captured on a single occasion, the percentage of parity in one aliquot, with the number of eggs matured by an equal aliquot after complete engorgement on a hamster. In order to correlate the number of ovarioles matured with the number of eggs laid in a natural oviposition, 6 lots of fed females, isolated and observed up to 7 days after the first oviposition to count the total number of eggs laid, were included in this study.

\section{Material and Method}

\section{Source of $\mathrm{L}$. youngi}

Wild females were captured in an illuminated Shannon trap and confined in lots of 25 within glass vessels lined with laminated cork. They were fed on a $50 \%$ sucrose solution and kept in polystyrene cases at $85 \%$ relative humidity and $25^{\circ} \mathrm{C}$.

\section{Experimental technique}

Within $48 \mathrm{~h}$ of capture, females were engorged on the paws of hamsters anesthetized with pentobarbital. Those maintained for ovogenesis were dissected 5 days after the blood meal. A sample was dissected to determine parity, according to Márquez \& $\operatorname{Scorza}^{3}$ (1982).

For oviposition counts, females were kept individually in glass -vessels with a bottom of damp plaster; the eggs laid up to 7 days -after the first appearance of eggs were counted.

For counts of matured ovarioles, lots of 25 females each were engorged and kept as above for $120 \mathrm{~h}$ after the meal. They were then anesthetized with ether, submerged in $1 / 10,000$ Triton X-100 in saline, and dissected for counting eggs, under $100 \mathrm{X}$ magnification.

\section{Work plan}

In a previous paper (Márguez \& Scorza ${ }^{4}$, 1984) on the population dynamics and parity of $L$. youngi in the city of Trujillo, an increase in the number of parous females in the second semester, after a second peak of precipitation, was reported. The first naturally infected insects were found at the end of the second semester.

The present work includes a study of the changes of the population density of the vector. The figure shows the dates of collection related to the precipitation profile (solid line).

\section{Statistical analysis}

Data were analysed by analysis of variance for two variables and differing values of $N$. The Duncan test was used to compare the associations of the various lots of insects.

\section{Results and Commentary}

\section{Females for oviposition}

Six lots of females, labelled A to F, were studied - a total of 90 females that survived to oviposition. Table 1 presents the number of eggs laid by each lot of females with the values of $\overline{\mathrm{x}} \pm \sigma$ and $\mathrm{N}$ for each lot (Table 1 ).

Analysis of variance for two variables, and with different numbers of eggs/lot of females gave a statistical $\mathrm{F}$ of 10,951 with $\mathrm{P} \leq 0.01$, indicating significant differences between the lots. A Duncan test to determine similarities and differences between the lots gave the values presented in Table 2 .

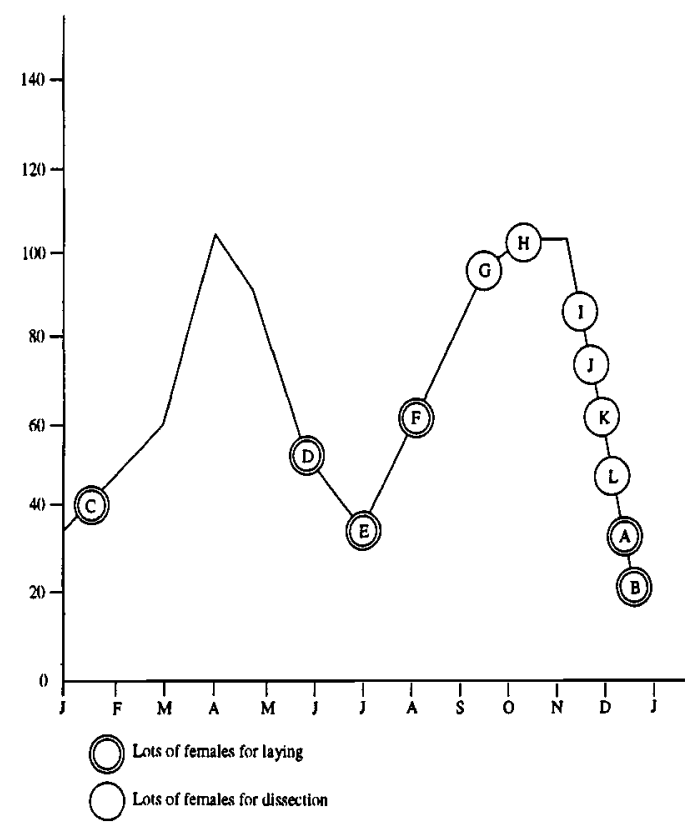

Figure. Rainfall regime showing sampled lots. Trujillo, 1986. 
Table 1. Number of eggs laid by six different lots of $L$. youngi females captured on different dates.

\begin{tabular}{|c|c|c|c|c|c|c|}
\hline \multirow{2}{*}{ Female $N^{2}$} & \multicolumn{5}{|c|}{ Lots of L. youngi } & \multirow[b]{2}{*}{$F$} \\
\hline & A & $\mathrm{B}$ & $\mathrm{C}$ & $\mathrm{D}$ & $E$ & \\
\hline 1 & 17 & 43 & 22 & 15 & 12 & 40 \\
\hline 2 & 47 & 34 & 39 & 18 & 8 & 9 \\
\hline 3 & 20 & 6 & 12 & 16 & 12 & 37 \\
\hline 4 & 21 & 2 & 55 & 26 & 13 & 59 \\
\hline 5 & 25 & 9 & 24 & 8 & 6 & 41 \\
\hline 6 & 30 & 2 & 10 & 8 & 15 & 32 \\
\hline 7 & 22 & 48 & 50 & 7 & 9 & 66 \\
\hline 8 & 12 & 18 & 5 & - & 6 & 8 \\
\hline 9 & 6 & 2 & 51 & - & 22 & 37 \\
\hline 10 & 26 & 23 & 33 & - & 10 & 28 \\
\hline 11 & 15 & 15 & - & - & 8 & 24 \\
\hline 12 & 40 & 24 & - & - & 15 & 26 \\
\hline 14 & 40 & 17 & - & - & 19 & 48 \\
\hline 15 & 5 & - & - & - & 22 & 52 \\
\hline 16 & - & - & - & - & - & 17 \\
\hline № & 15 & 14 & 10 & 7 & 15 & 16 \\
\hline $\bar{x}$ & 23.4 & 19.1 & 30.1 & 14.0 & 11.9 & 40.8 \\
\hline$\sigma$ & 12.2 & 14.9 & 18.3 & 6.9 & 5.5 & 17.5 \\
\hline Dates & 18 Jan & 25 Jan & 26 Feb & 26 Jun & $12 \mathrm{Jul}$ & $15 \mathrm{Aug}$ \\
\hline
\end{tabular}

The Duncan test detected no differences between lots $A$ and $B$, nor between $D$ and $E$, the lots labelled 'post-pluvial', these having been captured at the end of the two rainfall peaks. Neither were there detectable differences between lots $\mathrm{C}$ and $\mathrm{F}$, labelled 'pre-pluvial' and captured at the beginning of the rainfall peaks. There were differences between the pre-and post-pluvial lots for each rainfall peak. Lots $\mathrm{A}, \mathrm{B}$ and $\mathrm{C}$ are similar; they were captured in periods of little rainfall. On the other hand, lot F, captured at the beginning of the second rainfall peak, is different from the lots captured at the ends of the two rainfall peaks ( $A$ and $B, D$ and $E$ ). These differences are epidemiologically significant, since, according to our hypothesis, the variation in the average number of eggs laid by females captured at different stages of the rainfall cycle should reflect the changes in population composition throughout the year. Females captured at the beginning of the rainfall peaks laid a large number of eggs (C: 30.1 av., F: 40.8 av.). Females taken at the end of the rainfall peaks

Table 2. Duncan multiple range test for means and variances of number of eggs laid by females from six different lots.

\begin{tabular}{ccccccc}
\hline \multicolumn{2}{c}{ Treatments } & & & & & \\
& E & D & B & A & C & F \\
\hline E & - & 2.13 & 7.27 & 11.53 & $18.23^{*}$ & $28.29^{*}$ \\
D & - & - & 5.14 & 9.40 & $16.10^{*}$ & $26.79^{*}$ \\
B & - & - & - & 4.00 & 10.70 & $21.39^{*}$ \\
A & - & - & - & - & 6.79 & $17.39^{*}$ \\
C & - & - & - & - & - & 10.69 \\
F & - & - & - & - & - & - \\
\hline
\end{tabular}

* Highly significant laid fewer eggs (A and B, D and E).

\section{Females for dissection}

To compare the egg yield, counted by dissection at the end of a gonotropic cycle for a given lot of insects captured on a particular occasion, to the parous condition of an alicuot of insects taken from the same lot, these left to oviposit naturally, three ranges of oviposition where taken: 30 eggs or less, 31-60 eggs and 61 or more eggs. In other words, according to our hypothesis, there would be nulliparous females maturing 60 or more eggs, parous females maturing 31-60 eggs, and multiparous females maturing no more than 30 eggs. In a given lot of insects, there all three conditions of females would be found, but the predominance of one or another would indicate the physiological age of the lot.

Table 3 presents the results of the dissection of 6 lots of $L$. youngi captured on different dates, the percentage of females maturing eggs in each of the 3 ranges, the percentage of eggs/female, the percentage of parous females, the density of insects $/ \mathrm{m}^{2}$ for the date, and the particular period of the annual rainfall cycle. It will be seen that lots $\mathrm{G}$ and $\mathrm{H}$, the captures of 18 and 25 October, just prior to the second rainfall peak, contained a high percentage of females with more than 60 eggs (71 and $83 \%$ ), while the percentage of parous females was low (28 and 14\%). The average number of eggs/female was also high (67 and 71), with relatively little variation $( \pm 25$ and $21 \%$ ). The lots I, J, K and L of 3, 28 and 29 November, and from 2 December, respectively, taken during the full rainy season, show a higher 
Table 3. Percentage proportion of females with low, medium and high number of eggs related to rainfall regime, sandfly density and percentage of parous females in each lot.

\begin{tabular}{|c|c|c|c|c|c|c|c|c|c|}
\hline \multirow{2}{*}{ Lot } & \multirow{2}{*}{$\begin{array}{c}\text { Xy } \sigma \\
\text { of eggs }\end{array}$} & \multirow{2}{*}{$\begin{array}{l}\text { Date for } \\
\text { sampling }\end{array}$} & \multicolumn{4}{|c|}{ Eggs from wild females } & \multirow[t]{2}{*}{ Rain period } & \multirow{2}{*}{$\begin{array}{c}\% \text { of } \\
\text { parous }\end{array}$} & \multirow{2}{*}{$\begin{array}{c}\text { Sandflies } \\
\text { per } \mathrm{m}^{2}\end{array}$} \\
\hline & & & $\begin{array}{l}30 \text { or } \\
\text { less }\end{array}$ & $31-60$ & $\begin{array}{l}60 \text { or } \\
\text { more }\end{array}$ & $\mathbf{N}$ & & & \\
\hline $\begin{array}{l}G \\
H \\
I \\
J \\
K \\
L\end{array}$ & $\begin{array}{l}67 \pm 17 \\
71 \pm 15 \\
30 \pm 19 \\
51 \pm 16 \\
50 \pm 14 \\
46 \pm 24\end{array}$ & $\begin{array}{c}18 \text { Oct. } \\
25 \text { Oct. } \\
3 \text { Nov. } \\
28 \text { Nov. } \\
29 \text { Nov. } \\
2 \text { Dec. }\end{array}$ & $\begin{array}{c}10^{*} \\
0 \\
41 \\
20 \\
16 \\
32 \\
\end{array}$ & $\begin{array}{l}18 \\
17 \\
39 \\
56 \\
49 \\
41\end{array}$ & $\begin{array}{l}71 \\
83 \\
20 \\
24 \\
35 \\
27 \\
\end{array}$ & $\begin{array}{c}49 \\
18 \\
49 \\
122 \\
74 \\
41 \\
\end{array}$ & $\begin{array}{c}\text { Prepluvial } \\
\text { Prepluvial } \\
\text { Pluvial } \\
\text { Pluvial } \\
\text { Pluvial } \\
\text { Pluvial } \\
\end{array}$ & $\begin{array}{l}28 \\
14 \\
76 \\
45 \\
40 \\
56 \\
\end{array}$ & $\begin{array}{c}100 \\
110 \\
100 \\
50 \\
60 \\
160 \\
\end{array}$ \\
\hline
\end{tabular}

* Percentage of females from each sampling with their number of eggs.

percentage of parous females ( $76 \%$ for lot I and $40 \%$ for lot $\mathrm{K}$ ). Lot I showed the highest percentage of females maturing 30 eggs or less $(41 \%)$, and the highest percentage of parous females $(71 \%)$. Lot L, taken a month later, had $32 \%$ of females maturing 30 eggs or less, and $57 \%$ parous females. The number of insects dissected per lot bore a more or less fortuitous relation to the number of insects captured; however, more were dissected from lot J, of relatively less abundance, since the time of capture was extended on that occasion.

Inspection of Table 3 reveals an interesting relationship between oviposition, parity, and rainfall. Lots $\mathrm{G}$ and $\mathrm{H}$, taken in the prepluvial period, showed maximum oviposition, highest percentage of females maturing 60 or more eggs, and the lowest percentages of parous females. Lot $I$, at the beginning of the rainy season, taken only 9 days after lot $H$, showed the minimum oviposition, the lowest percentage of females maturing 60 or more eggs, and the highest percentage of parous females. Lots $\mathrm{J}$ and $\mathrm{K}$, taken 25 and 26 days after lot I, naturally showed very similar values for oviposition and parity. However, oviposition and eggs/female were higher, and parity lower than in lot I. Density of adult $L$. young $\mathrm{i} / \mathrm{m} 2$ was relatively constant from 18 October to 3 November (lots G, H, I), fell abruptly on 28 and 29 November (lots $J$ and $K$ ), and increased by almost 200\% 3 days later (lot L, 2 December).
As a speculation, it may be suggested that the popolation of these insects, increasing from 40 to $100 / \mathrm{m} 2$ as the rainfall begins to increase, contains a large percentage of young, nulliparous females (Márquez \& Scorza ${ }^{4}, 1984$ ). The accumulate precipitation $(200 \mathrm{~mm})$ has a catastrophic effect on the population density of L. youngi (Márques \& Scorza ${ }^{4}$ ), possibly inhibiting emergence of new females and allowing fewer adults to survive, thus increasing the proportion of parous or older females. When the rains again diminish, the population tends to re-establish itself by re-oviposition, young females reappearing, but in lower percentage than females that have completed one or more gonotropic cycles.

A similar analysis, from lots $A$ to $F$, may help to clarify these findings (Table 4).

A point to he noted is the low number of spontaneously laid eggs in relation to the number actually matured. This is inherent in the species. Females of those species that habitually die in captivity during oviposition, such as $L$. longipalpis retain up to $40 \%$ of the eggs produced (Killick-Kendrick et $\mathrm{al}^{1}$ ). In contrast, those species that oviposit in the laboratory without difficulty, survive and refeed, such as $L$. flaviscutellata expel all the eggs produced (Ward ${ }^{12}, 1977$ ). This has forced us to reduce the ranges for females ovipositing in the laboratory to 20 or less, $21-40$ and 40 or more.

Table 4. Percentage proportion of females with low, medium and high number of eggs laid spontaneously and their relationship to the rainfall regime.

\begin{tabular}{|c|c|c|c|c|c|c|c|c|c|}
\hline \multirow[t]{2}{*}{ Lot } & \multirow[t]{2}{*}{$\begin{array}{l}X \text { and } \sigma \\
\text { of eggs }\end{array}$} & \multirow[t]{2}{*}{$\begin{array}{l}\text { Date of } \\
\text { sampling }\end{array}$} & \multicolumn{4}{|c|}{$\begin{array}{l}\text { Percent of females in cach lot } \\
\text { with the number of eggs laid }\end{array}$} & \multirow[t]{2}{*}{ Rain period } & \multirow[t]{2}{*}{$\begin{array}{l}\% \text { of } \\
\text { parous }\end{array}$} & \multirow[t]{2}{*}{$\begin{array}{l}\text { Sandflies } \\
\text { per } \mathrm{m}^{2}\end{array}$} \\
\hline & & & $\begin{array}{l}20 \text { or } \\
\text { less }\end{array}$ & $21-40$ & $\begin{array}{l}41 \text { or } \\
\text { more }\end{array}$ & $\mathrm{N}$ & & & \\
\hline $\begin{array}{l}A \\
B \\
C \\
D \\
E \\
F\end{array}$ & $\begin{array}{c}23.4 \pm 12 \\
19.1 \pm 14.9 \\
30.1 \pm 18.3 \\
14.0 \pm 6.9 \\
11.9 \pm 5.5 \\
40.8 \pm 17.5\end{array}$ & $\begin{array}{c}18 \text { Jan. } \\
25 \text { Jan. } \\
26 \text { Feb. } \\
26 \text { Jun. } \\
12 \text { Jul. } \\
15 \text { Aug. }\end{array}$ & $\begin{array}{l}33 \\
57 \\
30 \\
86 \\
87 \\
10\end{array}$ & $\begin{array}{l}60 \\
29 \\
40 \\
14 \\
13 \\
41\end{array}$ & $\begin{array}{c}7 \\
14 \\
30 \\
0 \\
0 \\
49\end{array}$ & $\begin{array}{c}15 \\
14 \\
10 \\
7 \\
15 \\
29\end{array}$ & $\begin{array}{l}\text { Postpluvial } \\
\text { Postpluvial } \\
\text { Prepluvial } \\
\text { Postpluvial } \\
\text { Postpluvial } \\
\text { Prepluvial }\end{array}$ & $\begin{array}{l}50 \\
30 \\
80 \\
60\end{array}$ & $\begin{array}{l}30 \\
40 \\
30 \\
50 \\
60 \\
60\end{array}$ \\
\hline
\end{tabular}


Lots A and B (18 and 25 January) and lots D and $E$ ( 26 June and 12 July) captured toward the end of each of the two annual rainfall peaks, laid fewer eggs than did lots C and F (26 February and 15 August), captured toward the beginning of the peaks. Table 1 shows that lots $C$ and $F$ laid the highest average number of eggs and had the highest average of eggs/female. It appears that the $C$ and $F$ prepluvial population might have high numbers of recently emerged females, nulliparous or possibly primiparous, with little hematophagy, while lots A and B, lots D and E, postpluvial, might consist mostly of females which had survived the heavy rains that had diminished adult densities (Márquez \& Scorza ${ }^{4}$, 1984 ), these females probably being multiparous.

The relationship between $L$. young $i$ females infected with Leishmania braziliensis and the higher frequency of adult Didelphis marsupialis (Scorza et al.6, 1984 and Telford et al. ${ }^{10,11}, 1979$ ) is epidemiologically significant. In our locality, during June and July, the population of $L$. youngi has a high percentage of parous females, many of these expelling an average of less than 20 eggs/female. This season of actively biting females coincides with the highest seasonal percentage of young $D$. marsupialis.

\section{Conclusions}

Counts of the eggs matured by wild-caught female $L$. youngi fed upon hamsters and dissected after the blood meal, have suggested a relation between egg number and physiological age. Females captured toward the end of the rainy seasons tend to have fewer ovarioles per ovary (Márquez \& Scorza ${ }^{4}, 1984$, Fig. 3, p. 236). Since it is difficult to determine the parity of a female, beyond establishing parity or nulliparity, a technique has being developed by our group for differentiating young populations composed mainly of nulliparous females, and old populations with high percentages of multiparous females.

Six lots of $L$. youngi females, captured at the beginning, middle, and end of the year, in different phases of the rainfall cycle, have been studied. By comparing the numbers of eggs matured with the parity of the females in each lot, using one sample of females for counts of eggs matured, and another sample from the same lot to determine parity, it was possible to establish a link between the reproductive behavior of the insect and the dynamics of the precipitation profile. In brief, the lots of insects captured at corresponding points of the two annual rainfall peaks show very close affinities, as revealed by the Duncan test (Table 2). Significant differences were of the order of $P$ equal to 0.01 . Prepluvial females had a lower percentage of parity and matured more eggs than postpluvial females.

Colonization of this species in the laboratory would allow confirmation of the population dynamics described here, and would permit correlation of the transmission of cutaneous leishmaniasis with the physiological age of the vector population. This would, in turn, establish the optimum period for control of the vector by aerosol insecticides.

SCORZA, J.V. \& OVIEDO, M. [Edad fisiológica de poblaciones de Lutzomyia youngi (Diptera: Psychodidae) de una área endémica de leishmaniasis cutánea] . Rev. Saúde Pública, 28: 400-5, 1994. Con lotes de hembras silvestres de Lutzomyia youngi (Phlebotominae) capturadas con trampa de Shannon en doce ocasiones a lo largo de un año, en una localidad endémica para leishmaniasis tegumentaria, próxima a la ciudad de Trujillo, Venezuela, se estudio: 1) los percentajes de hembras paridas según criterios previamente establecidos y 2) el número medio de huevos puestos espontaneamente por hembras aisladas, en el curso de 7 días postigestión, ingurgitadas también sobre hámsteres. Se comparó la data de lotes de hembras capturadas, en noches de días anteriores a los periodos de lluvias (prepluviales) con las de hembras capturadas después de las lluvias (postpluviales). Se detectó diferencias significativas por análisis de varianza para dos variables y diferente número de $\mathrm{N}, \mathrm{y}$ también consistentes agrupaciones con la prueba de Duncan para lotes de hembras pre y postpluviales. Las hembras capturadas en noches previas a los periodos de lluvias (Enero - Marzo y Agosto - Septiembre) exhibieron más altas tasas de nuliparidad (86-72\%) y contuvieron o eliminaron mayor número de huevos (71-67), que las hembras capturadas después de las lluvias (Marzo-Junio y Noviembre - Diciembre), con mas bajas tasas de nuliparidad (60-24\%) y menores números de huevos (5030). Los picos de lluvias ocurrieron en Abril y Septiembre - Octubre, respectivamente. Se considera que estas diferencias puedan ser utilizadas, como una estimativa de la edad fisiológica de problaciones de hembras de $L$. youngi, en estudios epidemiologicos.

Descriptores: Psychodidae, fisiología. Oviposición, fisiología. Ecologia de vectores.

\section{References}

1. KILLICK-KENDRICK, R.; LEANEY, A.J.; READY, P.D. The establishment, maintenance and productivity of a laboratory colony. of Lutzomyia longipalpis (Diptera: Psychodidae). J. Med. Entomol., 13:429-40,1977.

2. MAGNARELLI, L.A.; MODI, G.B.; TESH, R.B. Follicular development and parity in Phlebotominae sand flies (Diptera: Psychodidae). J. Med. Entomol., 21:681-9, 1984. 
3. MÁRQUEZ, M. \& SCORZA. J.V.Criterios de nuliparidad y de paridad en Lutzomyia townsendi (Ortiz, 1959) del occidente de Venezuela. Mem. Inst. Oswaldo Cruz, 77:229-46,1982.

4. MÁRQUEZ. M. \& SCORZA, J.V. Dinámica poblacional de Lutzomyia youngi (Ortiz, 1959) (Diptera: Psychodidae) y su paridad en Trujillo, Venezuela. Bol. Dir. Malariol. Saneam. Amb., 24: 8-20,1984.

5. READY, P.D.; LAINSON, R.; WILDIES, T.J.; KILLICKKENDRICK, $R$. On the accuracy of age-grading neotropical phlebotomines by counting follicular dilatations: first laboratory experiments using colonies of Lutzomyia flaviscutellata (Mangabeira) and L. Furcata (Mangabeira) (Diptera:Psychodidae). Bull. Entomol. Res., 74: 641-5. 1984.

6. SCORZA, J.V.; MÁRQUEZ, M.; MÁRQUEZ, J.C. Hallazgo de Lutzomyia townsendi (Ortiz, 1959) naturalmente infectada con Leishmania braziliensis, en el área suburbana de Trujillo. Venezuela. Bol. Dir. Malariol. Saneam. Amb., 24:21-8, 1984.

7. SCORZA, J.V.; MACÍAS, P.; ROJAS, J. Encuesta epidemiológica sobre leishmaniasis cútanea urbana en la ciudad de Trujillo, Venezuela. Bol. Dir. Malariol. Saneam. Amb., 25: 73-81, 1985.

8. SCORZA, J.V.; REZZANO, S.; MÁRQUEZ, J.C. Didelphis marsupialis, reservorio primario de Leishmania spp. en la ciudad de Trujillo, Venezuela. Bol. Dir. Malariol. Saneam. Amb., 26:1-5,1986.
9. SCORZA, J.V.; HERNÁNDEZ, A.; VILLEGAS, E.; MÁRQUEZ, J.C.; MARCUCCI, M.Efectividad del Nysoral $^{R}$ (Ketoconazol) para el tratamiento de las leishmaniasis cutánea y cutáneomucosa en Trujillo, Venezuela. Bol. Dir. Malariol. Saneam. Amb., 28: $32-9,1988$

10. TELFORD, S.R. \& GONZÁLEZ, T. Densidad, área de distribución y movimiento de poblaciones de Didelphis marsupialis en los llanos altos de Venezuela Bol. Dir. Malariol. Saneam. Amb., 19:119-28,1979.

11.TELFORD, S.R.; GONZÁLEZ, J.J.; TOWN, R.J. Reproducción y crecimiento de Didelphis marsupialis, un huesped reservorio primario de enfermedad de Chagas en los llanos altos de Venezuela. Bol. Dir. Malariol. Saneam. Amb., 19(2): 44-56, 1979.

12. WARD, R.D. The colonization of Lutzomyia flaviscutellata (Diptera: Psychodidae), a vector of Leishmania mexicana amazonensis in Brazil. J. Med. Entomol., 14: 469-76, 1977.
Submitted in 10.27.1993

Reviewed in 9.6 .1994

Approved in 10.24.1994 